\title{
THE JOURNEY FROM UNTOUCHABLE TO DALIT: PIONEERING LITERARY LANDMARKS AND DISSIDENT DALIT VOICES OF CONTEMPORARY INDIA
}

\author{
Ana Garcia-Arroyo, Universidad de Valencia \\ Emaill: garciaarroyo7@gmail.com \\ amagara2@uv.es
}

\begin{abstract}
This paper analyses the situation of Untouchable / Dalit people in India through intersecting literature and social realities. It focuses on the most relevant and pioneering literary works of colonial and postcolonial times and how these landmarks of fiction function as a mimetic expression of everyday life. Then, the main objective is 1) to give an overview of the representation of untouchability and its evolution into the Dalit consciousness within the interrelated contexts of literature and real life; and 2) to demonstrate that in much less than a century India has witnessed astonishing changes as far as the social stratification of caste-gender is concerned.
\end{abstract}

Keywords: untouchability, Dalit identity, pioneering Dalit literature, gender-caste discrimination

Resumen: Este artículo analiza la situación de los/as intocables o Dalits en India, interrelacionando realidades literarias y sociales. Se examinan las obras literarias pioneras de la etapa colonial y postcolonial y cómo éstos textos de ficción mimetizan la realidad diaria. Así, el objetivo principal es 1) exponer cómo se ha representado la intocabilidad y cuál ha sido su evolución hasta la formación de la consciencia Dalit, en el contexto literario y social; y 2) demostrar que en menos de un siglo se han producido asombrosos cambios en lo que se refiere a la categoría social de casta-género.

Palabras clave: intocabilidad, identidad Dalit, literatura pionera Dalit, discriminación de género-casta.

\section{INTRODUCTION}

Everybody is aware of the Indian tradition of varna, which is nothing else than the caste concept and caste categorization of human beings. The complex varna system could be ranging between four and five thousand castes nowadays. Far from what Dumont categorically stated in Homo Hierarchicus. The Caste System and Its Implications (1981), which was a popular text, where the notion of caste is reduced to an ontologically religious organism, in contemporary times the Indian anthropologist, Agustin Panikker, demonstrates in his latest research, La sociedad de castas. Religion y política en la India (2014), that caste in India is a complex and comprehensive system of life including food, worship, 
marriage, education, community, occupation, clothes, customs, regions, and much more. Caste then implies an amalgamation of different complex social-cultural factors that share an interrelation of power. Panikker also argues that Hindu orthodoxy has been ruled by the highest caste of the social categorization, the Brahmins, who have imposed the dogma of Brahmanic superiority to the other subgroups. Among the immense number of castes, the untouchables have been the ones exposed to the most inhuman degradations, practised by all those above them in the social system of power relations. They have been treated as almost another race of beings for their falsely attributed inferiority.

This paper will analyse the situation of Untouchable / Dalit people in India through intersecting literature and their social realities. It will focus on the most relevant and pioneering literary works of colonial and postcolonial times and how these landmarks of fiction function as a mimetic expression of everyday life. In this way, as the Norton Anthology of Theory and Criticism (2001) illustrates, "the knowledge it [literature] conveys is of the 'cultural unconscious', that is, of the archive of historical words, symbols, codes, instincts, wishes, and conflicts characteristic of a people and its era" (Leitch, et alt 2001: 6). In other words, "literary texts have become more widely recognised as materials that are essential for historical study" (Loomba 1998: 81). Thus, the literary works and reports selected here are important to be discussed because they act as social documents that mimetically narrate the hardships and achievements of the lowest caste in Indian society. All in all, the main objective is 1) to give an overview of the representation of untouchability and its evolution into the Dalit consciousness within the interrelated contexts of literature and real life; and 2) to demonstrate that in less than a century India has witnessed astonishing changes.

\section{THE MACHINE THAT CLEANS DUNG}

As early as 1935, the writer Mulk Raj Anand, one of the so called 'fathers' of Indian English Literature, published Untouchable, which became a literary landmark and a controversial novel, owing to the depiction of physical, moral and mental anguish of the downtrodden. Anand thoroughly exposed the miseries and human aberrations under colonial rule. His modernist account of a day in the life of Bakha, a sweeper and latrine cleaner, soon became a great success. Since its publication until contemporary times many things have changed as far as the real situation of the outcaste in India is concerned. Even the writer, who died in 2004, could witness the gradual transformation of India from a feudal society into a capitalist and global country. The first pages of the novel overtly introduce the reader to the historical circumstances of the 1930s and 40s. In these first paragraphs Anand describes the geopolitical situation of the outcastes' colony, which is conveniently situated far apart from the town and cantonment. From this very beginning he explicitly narrates the abject conditions of his protagonist, Bakha, living among the dirt and filth of the public latrines and his dingy, one-roomed mud-house. In fact critics have praised Anand for "its photographic fidelity of realist representation, for placing a certain previously invisible population of Indian society on the map" (Baer 2009: 577). From this onset the reader also discovers the relation between Bakha, the subaltern, to use Spivak's terminology ${ }^{1}$, and

1 See: "Can the Subaltern Speak?" By Gayatri C. Spivak, in which she interrogates the (in)capacity of the subaltern or colonized to speak. 
the British and other Hindus. At a local and micro level, Bakha admires and imitates the Tommies / British because they treat him better than the Hindus. He desires equality, which is unattainable within the fixed stratification of the caste system and its rigid traditions on pollution that Anand fiercely criticizes. Also, at a macro level Anand points out the relation between the metropolis, or the British, and the colony, that is to say, India. In other words, the writer focuses on the relationship between the colonized (or subaltern) and the colonizer.

Having spent a substantial and formative period of his life in London and being slightly connected with the intellectuals of the Bloomsbury circle from his motherland, Anand writes back the colony, India, to the modernist voices and political leaders of the metropolis $^{2}$. Not only does he expose the abominable conditions of the most marginal individuals in his own country, characters like Bakha, who are oppressed by Brahmins and other high castes, but also, in a more subtle form, he critiques the dangers of colonization that have indiscriminately submitted all Indians throughout centuries. A reading between the lines suggests that what Anand seems to illustrate is what Gurcharan Das discusses in his article, "If We Were Once Rich, Why Are We Now Poor?". Das genuinely conveys the idea that the English came to India to plunder rather than to trade. When they left at the time of Independence, India was a large non-industrial and extremely poor country with "unfavourable conditions, such as a debilitating land tenure system, low standards of efficiency and integrity in public administration, weak participation of the people in local affairs, a rigid and unequal social structure" (Das 2002: 67).

Within this system of unequal power relations that the novel depicts we realize that oppression and abuse do not only take place within vertical categorizations of individuals, such as in the pairs colonizer-colonized/subaltern; or Brahmins-outcastes, but also at a horizontal level. Baer expands this argument when he expresses that Bakha will become a human being:

by reimposing a law of hierarchical difference upon the other untouchables, by figuratively taking the first step in becoming a colonial sub-oppressor [...] He accedes to an awakening consciousness of shared humanity as well as expressing contempt for the abjectness of his untouchable fellows (Baer 2009: 578).

The concept of the 'sub-oppressor', who also overuses power, is very typical of patriarchal societies, and literature and history have left us many examples. At a horizontal dimension or level a male untouchable, who is oppressed by a member of a higher caste, also exercises his authority by unscrupulously abusing his wife, children or younger males. Likewise, a mother can humiliate her daughter and servant. We find a good example of this horizontal level of oppression in Arundhati Roy's novel The God of Small Things (1997), when the untouchable, Velutha, is oppressed by the touchables. Likewise, the touchable Ammu is ostracised by her own family and community for being a divorced woman. Suresht Renjen Bald, who interviewed Anand in 1974, provides another example of vertical and horizontal abuse. The writer himself was beaten, degraded and punished by both the colonizer and his own family:

2 For this idea of writing back or responding to the empire, see the pioneering text in Postcolonial Studies, The Empire Writes Back by Bill Ashcroft, Gareth Griffiths and Helen Tiffin. London: Routledge, (1989) 2004. 
As a 14-15-year-old boy, Mulk Raj was a victim of General Dyer's flogging order. He received eleven stripes on the back. His father scolded him bitterly for going where he could be flogged, and threw mother and son out of the house. Later, Mulk Raj was not allowed to marry the muslim girl he loved" (Bald, 1974: 477).

Influenced by the historical events of India in the 1930s and 40s, Anand's novel helps us to gain insight into the Gandhian theme. Anand was a direct witness of the political and social upheavals during the 1930s Civil Disobedience movement with Gandhi's non-violent programme. Let us also not forget that after retuning from England, Anand lived with Gandhi at his Sabarmati ashram where he read the story of Uka the sweeper, published in Young India, that inspired him in his creation of Untouchable (Gandhi 2003). It does not surprise us then that in order to make his novel more realistic, Anand decides to include the character of Gandhi at the end of Untouchable when, drawn by the crowd, Bakha finally comes to see the benevolent paternal figure of the Mahatma. However, Gandhi's declaration of untouchability as the greatest blot on Hinduism does not convince Bakha entirely and he will soon change his first impression:

As you all know, while we are asking for freedom from the grip of a foreign nation, we have ourselves, for centuries, trampled underfoot millions of human beings without feeling the slightest remorse for our iniquity (Anand 1940: 146).

Bakha felt thrilled to the very marrow of his bones. That the Mahatma should want to be born as an outcaste! That he should love scavenging! He loved the man (148).

If Bakha is first attracted by Gandhi's idealistic discourse, he realizes later that his release from his life degradation will not come from this side:

There was only one queer voice which dissented from all this.

'Gandhi is a humbug,' it was saying. 'He is a fool. He is a hypocrite. In one breath he says he wants to abolish untouchability, in the other he asserts that he is an orthodox Hindu. He is running counter to the spirit of our age, which is democracy. He is in the fourth century B.C. with his swadeshi and his spinning-wheel. We live in the twentieth (Anand 1940: 150).

Bakha does not seem to rely much on the messianic words of a charismatic Gandhi. Instead, he is more inclined to believe a poet who, as one among the crowd, announces that the problem of inequality will be solved with the machine that cleans dung.

Being a left-wing intellectual who had read Marx's works, Anand was ideologically fascinated by the practical figure of Jawaharlal Nehru, who would later become the first President of India after its independence in 1947. Undoubtedly, Anand was more seduced by Nehru's socialist ideas to combat the injustices of society and modernize the country than by Gandhi's traditional vision of life. Therefore, the novel reasonably has to conclude with 'the machine to clean dung', as a metonym for technology and modernization, which will eventually help to sweep up the stigma of untouchability. 
We could now interrogate if this has really been like that in India. We can question to what extent in the journey from colonial times until today's India, which has brought the country some kind of modernization, the gradual introduction of technology, the opening of Indian doors to foreign markets and the arrival of globalization in the 1990s, Indian society has been transformed so much, as to include the lowest in the social strata. If we take a quick glimpse at society and history after Independence, we can really affirm that Anand's novel was an anticipation of what was about to come. Through the novel we discover that the writer has high expectations that technology and modernization would eliminate the brand of disgrace for the untouchables. But were these expectations entirely fulfilled?

\section{RESISTING THE SYSTEM: DISSIDENT DALIT VOICES IN LIFE AND LITERATURE}

Let us move some steps forward in history to the 1970s approximately, when we can distinctly experience some of the positive transformation in Indian society. Firstly, the term 'untouchable', which was synonymous with extreme poverty, anguish, humiliation and distress, has now been substituted by the political word 'Dalit', which represents a social and literary movement. From Independence in 1947 to contemporary times this Dalit movement has been fighting for fair representation and justice. Originally, it had its roots in the struggles led by Dr. Bhim Rao Ambedkar, an untouchable himself, who had worked for the rights of untouchables. Remarkably, in a span of over four decades, from colonial times to the first decades after independence, Ambedkar had become the champion of Human Rights in India and the architect of the Indian Constitution. Being a lawyer by profession, he put the emphasis on the role of law and attacked Brahmanism for being the evil of all inequality. Through his writing and discourse he stressed that Hindu scriptures, especially the Manusmriti, were the creation of Brahmins to maintain their superiority and privileges. As early as December 25th 1927, the Manusmriti was burned in a symbolic act and Ambedkar demanded that society was democratized. Soon after in April 1930, in the First Round Table Conference ${ }^{3}$, Dr. Ambedkar, who was representing the Depressed Classes (the untouchables), made a legal claim to 1) equal citizenship and fundamental rights; 2) he declared untouchability illegal; 3) he asked for protection against discrimination; 4) he demanded adequate representation of the Depressed Classes in the Legislatures and in services; and 5) he requested the right to be educated and have resources for their education (Rao 2006). These demands, among many others, were later acknowledged and implemented in the Indian Constitution after independence.

Mulk Raj Anand was aware of these political agitations and historical landmarks of his time. As an intellectual witness, we can assume that he must have required little effort to foresee that the social betterment of the country in general and of the downtrodden in particular would gradually be coming from the enactment of legal and democratic reforms. However, the seeming freedom that came from Independence did not annihilate the ostracism of Dalits' lives. No doubt, Ambedkar liberated Dalits from mental slavery, giving them a

3 The Round Table Conference was a series of three conferences held in India between 1930-1932, organized by the British government to discuss constitutional reforms. 
new self-respect. However, despite his great work, exemplary life and the institutional changes, acute discrimination and atrocities against untouchables / Dalits have continued in post-independence India.

Owing to these on-going aberrations against untouchables, a new revolutionary consciousness arises and Dalit literature emerges in the 1960s, as a powerful strategy that empowers dissident voices and depicts their social realities. The term 'Dalit' first appeared in the works of Marathi writers ${ }^{4}$ and neo-Buddhists, who began to use this notion of 'Dalit identity' to express their anger, indignation and aspirations in their own writings (Shah 2001). Moreover, these writers were acquainted with the Black movement in the USA, which influenced their decision to express their experiences in provocative literary language. As a result I must underline that Dalit literature stands as one of the most strategic and effective tools of cultural resistance that the colonized Dalit employs. In other words, Dalit literary productions show "the capacity of the colonized subject to intervene in colonial discourse to contest it, change it, or generally make the voice of the colonized heard" (Ashcroft 2010: 44).

Among these pioneering literary Dalit voices Arjun Dangle stands out as an important name in the politics and literature of Maharashtra, who is also the founder of the militant youth organization, the Dalit Panthers, and the president of the Bharatiya Republican Party of India. In his edition of Poison Bread he writes:

With the spread of education in the rural areas, there began to develop a class of educated Dalit youth, who had hitherto been kept away from the local economic or political system. Their association with workers of the leftist movements in rural areas gave them the ability to understand the entire system (Dangle 1992: 253).

A period of intense poetry and autobiographies had just begun. These Dalit writers, mainly men, were not only interested in the depiction of their own lives but also in the social system, communalism and injustices of all kinds, in order to raise consciousness and produce an striking effect.

At this stage we can interrogate if Anand would ever have imagined when he published Untouchable in 1935 that some time later the voices of the same members of the Dalit community would be exercising power by writing their own stories that are not entertainment-oriented but real ones. Indeed, they are stories, essays and poetry that bring about their own revolution, because when one has the control of discourse, one has the control of representation, as Bill Ashcroft puts it in Post-colonial Transformation: "narrations are not neutral alternatives, but are themselves a feature of the power struggle continually waged in post-colonial societies" (2010: 89). An example of this contesting struggle for authority comes in the last lines of the following poem, "White Paper", by Sharankumar Limbale, which expresses:

4 Dalit writers started writing in Marathi but then they also use other languages in India, English included. 
My rights: contagious caste riots.

Festering city by city, village by village,

Man by man.

For that's what my rights are.

Sealed off, outcast, road-blocked, exiled.

I want my rights, give me my rights. [...].

My rights are rising like the sun.

Will you deny this sunrise? (Dangle 1992: 64-65).

The pioneering Dalit voice in the poem explicitly demands rights. Through selfnarratives, poems, essays, short stories and autobiographies, Dalit literature operates as counter-discourse against the oppression of higher-caste Hindus and the appalling reality of poverty. Dalit literature is then about human freedom, hope and transformation. It aims to subvert hegemonic power and disrupt the dominant discourse.

So far I have been referring to Dalit literature written by male writers but what happens with the realities of Dalit women? How do they differ form those of Dalit men and how are they represented in literature? Who are the first dissident female voices who seize literature to challenge the hegemonic discourse and write their own herstory?

Not surprisingly I have to highlight that unlike Dalit men writers, only a few Dalit women have managed to have their stories written. Their marginalized position in the literary world and in their community has produced this gender imbalance. A big problem for Dalit women is their lack of education, which is the result of the striking poverty in their families. This fact is confirmed by Rashida Manjoo's Report of the Special Rapporteur on Violence Against Women (June 2014), presented at the 26th session of the Human Rights Council of the United Nations, which denounces multiple forms of violence against Dalit women:

Many of those women are denied an education and economic opportunities, and perform dangerous and unprotected work, including bonded labour (debt bondage) and manual scavenging, which are both widely regarded as forms of forced labour and modern forms of slavery [...] While legislation has been adopted to eradicate bonded labour and manual scavenging, reports and interlocutors indicate that there is a consistent failure in the implementation of such laws and a tendency to minimize the significance of the problem (Manjoo 2014: 5).

However, as the title of this paper suggests this study focuses on the pioneering literary landmarks and the Dalit voices that have managed to disrupt the colonizing force. There are few Dalit women's stories published in Dangle's edition, Poisoned Bread (1992) that I mentioned before. Also this research praises what some other Dalit women have done to eliminate their voiceless and faceless situation, which consists of narrating the story of their life to someone who can document their autobiographical testimony. For these women, their lack of education has not stopped them from telling / co-writing their very diverse experiences of colonization as a method of subverting imperial/local power and manifesting Dalit consciousness. One of the earliest publications is Sumitra Bhave's Pan on Fire, originally collected in Marathi in 1988 and published in English by the Indian Social Institute (1988). Pan on Fire is a collection of eight illiterate Dalit women, who tell their 
accounts. These eight female storytellers come from different contexts, as regards family, age, education, religion or profession. Their afflictions are not impediments to realize that if they continued being silent, they would be further abused and discriminated as Dalit and women. The mere exposition of their major incidents in their lives has empowered them and made them feel the desire for action: some of them have joined political movements and assembled other women to gain consciousness and fight for their basic rights and freedom. The title Pan on Fire is not only a metaphor of what their lives are like, with multiple oppressions and adversities, but it also alludes to a poem by the 19th century Marathi poetess, Bahinabai Chaudhari, that expresses that you have to burn yourself first before eating your food.

Another example of pioneering Dalit women's literature is Viramma: Life of an Untouchable (1997), an autobiography co-authored by Viramma and Josiane Racine, and published in English by Verso. Also I must mention Urmila Pawar's prominent story, The Weave of My Life. A Dalit Woman's Memoir (2003), which has become a foremost literary landmark of Dalit literature. Pawar is an acclaimed short story-writer and a Dalit feminist who "challenges from a feminist consciousness the patriarchal domination and gender biases deeply rooted in both the public and private domains, in the dalit movement as well as in familial, and legal, social and religious practices" (Pawar 2003: xxvi).

The conditions and hardships of Dalit women in their tumultuous social Indian contexts, which they themselves narrate in their stories, are very different from the situation of Dalit men writers, who can enjoy more liberties. The remarkable difference is that the men hardly deal with issues concerning Dalit patriarchy, as their stories tend to focus on the public sphere rather than the intimacy of their homes. An example of this could be Narendra Jadhav's successful Outcaste (2003), a personalized Dalit saga of a son paying tribute to his father, where the women occupy a conventional second space. These men's stories pour emotions like cruelty, exploitation and aspirations but they tend to forget their own mothers, wives, sisters, daughters and the unequal relationships with them within the Dalit household. Instead, the narratives by Dalit women are unique in dealing with the patriarchal social order of their own communities and families, in an explicit, frank and sincere way. Besides addressing their powerless position in the social sphere and the hardships they have to undergo to combat injustices, Dalit women's narratives are introspective and let us have a furtive look into the particular traditions of each community, their family customs, their individual manners in kitchens, bedrooms and their own bodies/sexualities. One of the female storytellers, Ashoka, in Pan on Fire writes: "it must be generally understood and accepted in an ideal community that a woman is not a subordinate or a toy or a sex object, or a useful machine; she too has a body that tires, a heart, among her own desires. There must be an awareness of her as person" (Bhave 1988: 150). These words highlight the fact that Dalit women, whether in literature or in real life, or both, are breaking down ancient caste and gender barriers.

Going back to Anand's Untouchable, our departing novel to trace the evolution of untouchables into Dalits and establish the interrelations between life and literature, we learn that the fictional protagonist, Bakha, relies on the introduction of technology to be rescued from his miserable position. His faithful belief in mechanized sanitation seems to be the only answer possible to his abjection. Indeed, technology, the development of 
capitalism, the implementation of democratic laws and the rise of political consciousness and desirable equality by Indians in general are factors that have contributed to weakening the caste system. Also, today technology has produced new political realignments and global networks such as the International Dalit Solidarity Network (IDSN), the biggest international civil organization focussing on Dalits issues to "link grassroot priorities with international mechanisms and institutions in order to change policies and practices that lead to caste discrimination. Through engagement with the UN, EU and other multilateral institutions, IDSN has had a significant impact on the internationalisation of caste discrimination as a critical human rights issue" (http://idsn.org/about-us/what-we-do/), which leads me to analyze more specifically the contemporary Dalit panorama.

\section{A DEPICTION OF THE CONTEMPORARY DALIT PANORAMA}

In the $21^{\text {st }}$ century the panorama that arises is still very complex and varied. On one hand there are Dalits who have held (o still hold) relevantly high positions. This has been the case of K.R. Narayanan, Kavali Pratibha Bharati and Meira Kumar, among others. Moreover, Meira Kumar happens to be the first Dalit woman Speaker of the Lok Sabha (Nag 2009). Likewise, Kavali Pratibha Bharati was a former Speaker of the Andhra Pradesh Legislative Assembly from 1999 to 2004. And Kocheril Raman Narayanan became the first Dalit President of India, who held the Presidency from 1997 to 2002. Thanks to a good education, the support of their families, their personal work and determination and their political involvement with the cause, these privileged Dalits have been able to surpass all kind of cultural boundaries. On the other hand, we realize that such personalities in such positions are representative of a minority who has benefited from India's policy of quotas in education and government jobs. But unfortunately a considerable number of Dalits still resemble Bakha, Anand's fictional character in Untouchable. The major trouble is not that they are still relegated to the most menial tasks such as manual scavengers, removers of waste, street sweepers or agricultural labourers, but usually their upper caste employers, either local authorities, private landlords or others, use their caste to continue exploiting them. In Broken People, a publication by Human Rights Watch (1999) we also read:

Dalit women face the triple burden of caste, class and gender [...] Sexual abuse and other forms of violence against women are used by landlords and the police to inflict political "lessons" and crush dissent within the community (1999: 2).

The democratic system of laws, responsible for granting Dalits opportunities for jobs and education, does not reach the large mass of them. Likewise legislations, designed to control atrocities and implement equality, seem to remain on bureaucratic paper. According to the revealing reports published in the International Dalit Solidarity Network (IDSN), even today the plight of most Dalit women condemns them to a life of exclusion, marginalization and disadvantage, as we often read in the headlines of different Indian papers. Some examples could be: "Pregnant Dalit woman eaten up for not disposing of cow carcass" (2016) by Mahesh Langa; or "The perils of being a Dalit in India" in The Hindu (2015); or "Dalit women stripped, beaten, paraded naked in UP village" (2015) by Srivastava; or "10 Injured 
in brutal attach on Dalit colony", reported in The Hindu (2014); or "Kannauj girl may never be able to see from left eye", in The Times of India (2011); or "Dalit girl burnt alive in Haryana village" in the Hindustan Times (2010). All these items of news speak about the ongoing attacks and abuses by higher-caste neighbours in rural and urban areas. They also remark the complexity and disparity related to the caste-gender system in India. Similarly, the 2015 Annual Report by the International Dalit Solidarity Network (IDSN), which is based on the document entitled "Access to Justice for Dalits in India", reveals that: "there has been a $19,4 \%$ increase in crimes against Dalits from the previous year. The number of cases registered under the PoA Act has also risen every year since 2011, taking a leap in 2014 to 47,064 cases against 13,975 cases in 2013" (2015: 17).

In "When Some Are Less Than Equal", published in The Times of India (Jun 13, 2011), the 1998 Nobel Prize in Economics, Amartya Sen, argues that in India some people have the handicap of 'caste' and / or 'gender' that prevents them from achieving their full potential in life:

In India, this could be caste, where a dalit schoolboy who is made to sit separately from other classmates is not able to fully actualise the benefits of an education. It could also be gender, where a woman employee who faces sexual harassment in an office is not able to perform to the best of her ability (Shrinivasan, 2011).

To contrast the above discriminatory and violent episodes, the press also reports the other side of $21^{\text {st }}$ century India that is undergoing positive changes and revolutionary transformations. From the Hindustan Times and the India Vision, we come across this headline: "Rajasthan's Dalit Women Celebrate 'Liberty' at Temple" (20 ${ }^{\text {th }}$ June 2011). For the first time in history in traditional Varanasi about two hundred Dalit women have performed rituals with the upper caste Hindus at the Vishwanath temple. Shanti Chaumaria, a manual scavenger, says: "For decades, we have faced hatred and discrimination"; and Shakuntala Chaumar, another scavenger, adds:

When people from upper castes assisted us in carrying out the rituals, for a while it all appeared like a dream. Though we have visited several prominent temples across the country, it was for the first time most of us got the opportunity of taking a dip in the Ganga" (Srivastava, 2011).

And one of the Brahmins who guided the women in their rituals expressed: "For the almighty, everyone is [the] same and equal. Why should there be any discrimination? These women are also a part of our society. We must make efforts for empowering them" (Srivastava 2011). Thanks to the help of Sulabh International, an NGO, these women have been rehabilitated. They gave up their old jobs as scavengers and got engaged in vocational jobs such as stitching, embroidery and pickle-making, for which they can get a monthly living of Rs. 2,000.

Also The Odisha Sun Times publishes the following headline, "Breaking Brahmin Monopoly: Temple to Have Women Dalit Priests" (2014) and highlights that another gender-caste bastion has crumbled, thanks to the support of the Supreme Court which has legally admitted Dalit women priests to perform the rituals of the temple. The centuries-old 
monopoly of Brahmins over religious rituals has started to be dismantled due to the constant struggle of Dalit women and all those civilians who support Human Rights.

Last but not least, I would like to refer to the outstanding story of Sampat Pal Devi and her group of women in pink saris, which has been reported by the national and international media in the last years. There has been a succession of headlines in Indian newspapers such as, "Gulabi Gang on the Prowl in Banda" by Atiq Khan in The Hindu (9 $9^{\text {th }}$ August 2006); or "The Power of Pink" by Priyasree Dasgupta in the Indian Express (28 ${ }^{\text {th }}$ March 2010). The news also appeared in the $B B C$, "India's 'Pink' Vigilante Women" by Souti Biswas; or in The Guardian, "SamPat Pal Devi”, (Saner, 8 March 2011); also in fashion magazines like Marie Claire, "Vigilantes in Pink" by Jan Goodwin (16 $6^{\text {th }}$ Jan. 2009) and in other European languages such as, Spanish, Portuguese, French, German, Italian or Czech. Films and videos have been released documenting the life and heroic commitments of Sampat Pal Devi and her women in pink, who call themselves The Gulabi Gang (http://www.gulabigang.org/en/ index.html). But what is extraordinary and pioneering about this woman? And how is her remarkable work connected to the main theme of this article?

Sampat Pal is a very low-caste woman and most of her 'gang' members are Dalits, who come from different villages in the district of Banda, one of the poorest parts of the state of Uttar Pradesh. In this rural area poverty is the cruellest violation of Human Rights. When people are extremely poor, corruption and exploitation of human beings come in all their forms and evils and override the land. The legal system and many police officers have become corrupt. Violence against women by husbands or families is daily routine and nobody cares for the poorest and downtrodden, the Dalits. In such feudalistic male-dominated society it is not strange that one day a heroic spirit from the lowest strata arises to combat injustice. Sampat $\mathrm{Pal}$ is that courageous woman with a strong determination to annihilate corruption, empower women and bring some dignity to both Dalits and non-Dalits. Her performance is an excellent example for other women to wield power and strike a hard blow against the normative gender-caste norms, especially in this area of Uttar Praddesh, where about 20\% of the population are born Dalits and the old rules still dictate where one should work and whom one should marry and when. With respect to untouchability Sampat Pal tells us in the film The Gulabi Gang produced by Journeyman Pictures SBS (2010):

How can people hate another human being? They do not even hate dog piss. If a dog pisses near the water where they are worshipping, they still drink that water. But they hate touching a human being that's why I have to do this. I've always argued and fought since childhood.

In fact Sampat Pal started her work and the formation of the association of women in the 1990s but it was only in 2006 when they adopted a uniform, a pink sari, when they started to be taken seriously. The uniform serves its psychological purpose of consciousnessraising. Pink (Gulabi) was chosen on the grounds that it has no association with any of the colours of the political parties. The pink sari makes them conspicuously visible and thus their struggle for justice and ethics becomes an issue of public concern. The private and local disputes of the underprivileged, either women or the poor, or both, have now trespassed the barriers of invisibility and have come into the public sphere, that is to say, the political terrain that demands Rights. 
Despite the fact that their auto-definition as 'gang' might produce a negative connotation, as it could be related to an illegal or criminal purpose, it has already been demonstrated that their actions and aims are far from this: theirs is simply a gang for Justice (with a capital). Besides the fluorescently pink sari, another sign that identifies them is the lathi, a traditional Indian stick that they all carry for self-defence.

Like a messiah of the poor, Sampat Pal's origins are humble. When she was very little she was sent to work on the family's land instead of going to school. Very soon, at 12 she was married to an unknown man and at 15 she had her first child. Four more children would follow soon. Today she still lives in relative poverty. She tells the TV programme Witness (2008) by the Aljazeera English Productions that she learnt to read because in her village there was a school and she used to go and peep in what was written. One day she was surprised by her uncle, so she told him she wanted to study and he arranged her admission to school, where she studied to class fourth.

Sampat Pal Devi and her group of women in pink march from village to village in the district creating awareness about women's empowerment, the rights of the poor, family welfare and children's education. Their aims also include stopping corruption and domestic violence. As they walk along the streets, with great conviction they sing: "Wake up women of India, the time has come to wake up" (Witness 2008). Bhagwati Devi, one of the members, affirms: "We have no hierarchy in our gang. We are all treated as equals and we work toward a common goal of removing corruption from the roots of society and bring justice to women." (Das 2008). And Chandania Devi, a fifty-five-year-old Dalit woman adds: "Ours is an untouchable village, so people from the upper caste do not come here and clearly nobody cares about the education system [...] After the initiative from Sampat Devi, we have a teacher and children can at least go to school" (Das 2008).

In the hot arid villages of the Banda district these women in pink have reversed all traditional gender-caste practices established. The rise of their voices against patriarchal norms, their speaking 'I', has become a privilege and "establishes a sovereign self, a center of absolute plenitude and power; speaking establishes 'the supreme act of subjectivity", (Butler 1999: 149). Likewise, their performance, to use Butler's gender terminology, reverses oppressive roles assigned to women: they fight for poor farmers and workers; they demonstrate in front of police stations and protest against the administration; they stop domestic violence and rescue women from brutal husbands; and they continue raising consciousness by chanting slogans such as: "Sisters, go on fighting, we are all behind you!" (Shagun Rastogi Films). Some examples of their main achievements are the following:

1)- A case of a Dalit woman that was raped by an upper-caste man. The police did not even register the incident and protestors who complained were arrested. Sampat Pal demanded the release of the villagers and the registration of the case. Protected by the 'supreme authority of the law', the police officers refused to listen to her request and as a result the Gulabi Gang had to use their lathis and force them to co-operate. In a land of corrupt lawmakers, her fight for the poor sometimes involves taking the law in her hands. She says in the documentary-film The Gulabi Gang: 
Why do I have to take the law into my hands? I'll tell you. The government does not obey its own laws. Police and government officials take bribes. Now people look up to me and do not go to the police. Sampat can do what the police can't (Journeyman Pictures 2010).

2)- One of the biggest struggles accomplished by The Gulabi Gang has been to get the 'Below Poverty Line Card' to some families who fall into the category of 'below poverty'. With this card the person is entitled to get fair-price rice and wheat from the government distribution centre. "I feel self-confident and much stronger", Banhari Devi asserts. She has also joined the gang after Sampat Devi rescued her.

3)- The Gulabi Gang discovered two lorries laden with grain that was destined to feed 'Below-Poverty-Line' people. The grain was going to be sold in the market and the money would be shared among the ones taking part, probably police officers and local authorities. And the poor, again, would be left with no food. The Gulabi Gang stopped the lorries and urged the local administration to hand over the shop owner to the police. The police even refused to register the case. Bijrania, a fifty year old Dalit, comments: "The police and the local administration intimidated us but we stood like a rock. We are a team and that's our strength. I was scared in the beginning but not anymore" (Das 2008).

4)- Sampat Pal has stopped many cases of domestic violence; she has instructed the family members to respect women. She has challenged the power of local authorities that automatically do not want to provide women and the poor with employment, or they give them a job but treat them as slaves (Journeyman Pictures 2010).

Sampat Pal constantly receives threats by those working for corrupt officers and local political parties. However, she is not scared and her journey from village to village continues, gathering more and more women who want to work for this cause of Justice. Her subversive performance has destabilized the naturalized categories of caste and gender to the extent that in the last years even men, like Jai Prakash Shivhari, have started to understand the importance of this movement and have joined this laudable fight. Sampat Pal's fame has reached an international level and countries such as France, Spain, Italy and Portugal collaborate with her work. Several sewing machines used in different working places round Uttar Praddesh have been financed by the members that the Gulabi Gang has abroad. In these stitching centres women can make a living and the young ones employed are specially benefited because now they bring money home, which means that their families have a good reason not to marry them off so early. Now they are proud of their self-confidence and independence and dare to raise their voices against cultural barriers.

Like the other Dalit women writers that I discussed above, Sampat Pal Devi has had her own story told in a book, Warrior in a Pink Sari (2009), which is co-authored with Anne Berthod. It was first published in French, Moi, Sampat Pal, Chef de gang en sari rose (2008), and in Spanish, El ejército de los saris rosas (2008). Her documentary account might not provide the reader the profound insight of Anand's modernist narration in Untouchable but it certainly conveys what a human being alone, a strong-minded courageous low-caste woman, is capable of doing to help individuals, families and communities to rebel against 
humiliation, suffering, oppressive traditions and corruption in their patriarchal local-global world. Moreover, her intentional performance has to be read as "a dramatic and contingent construction of meaning" (Butler 1999: 177).

\section{CONCLUSION}

After this long journey which like a winding river has hurried through the wide varied plain of untouchability, where the horizon of fiction mingles with the colourful limit of real life, I can conclude that the sources examined demonstrate that from Anand's untouchable protagonist, Bakha, in colonial times, to the $21^{\text {st }}$ century India, with exemplary women like Sampat Pal Devi and all the other pioneers discussed here, there have been moments of leaping and others of creeping. Mammoth challenges have been tackled and Dalits have emerged victorious, at times. The machine that cleans dung, that removes the anguish of the downtrodden, still has not come to some shady corners of the country, but here as well, in these wasted lands, where only corrupt weeds seem to grow, mother India has fertilised her own soil and from her own womb, out of her own fluid, extraordinary human beings of humble origins have been conceived. The battle against injustice continues but their immeasurable strength and commitment can do wonders.

\section{REFERENCES}

AnAnd, M. R. 1935. Untouchable. London: Penguin.

Ashcroft, B. 2010. Post-colonial Transformation. London \& New York: Routledge.

Ashcroft, B., Griffiths, G. \& Tiffin, G. 2004. The Empire Writes Back. London: Routledge.

BAER, B. C. 2009. "Shit writing: Mulk Raj Anand's untouchable, the image of Gandhi, and the progressive writers' association." Modernism /Modernity Vol 16 (3): 575-595.

BALD, S. R. 1974. "Politics of a revolutionary elite: a study of Mulk Raj Anand's novels." Modern Asian Studies Vol 8 (4): 473-489.

Bhave, S. 1988. Pan on Fire. Indian Social Institute.

Biswas, S. 2007. "India’s 'pink' vigilant women.” BBC News (November 26). "Breaking Brahmin monopoly: temple to have women Dalit priests”. The Odisha Sun Times. $14^{\text {th }}$ Sep 2015. http://odishasuntimes.com/2014/05/10/breaking-brahmin-monopolytemple-women-dalit-priests/

Butler, J. 1999. Gender Trouble. Feminism and the Subversion of Identity. New York: Routledge.

Dangle, A. 1992. Poisoned Bread. Translations from Modern Marathi Dalit Literature. London: Sangam Books. "Dalit girl burnt alive in Haryana village." Hindustan Times. 21 April 2010, http://www.hindustantimes.com/News-Feed/haryana/Dalit-girl-burntalive-in-Haryana-village/Article1-534141.aspx 
"Dalits leave village fearing Jat threat." Hindustan Times, Haryana 27 Jan. 2011. http:// www.hindustantimes.com/News-Feed/haryana/Dalits-leave-village-fearing-Jat-threat/ Article1-655145.aspx\#disqus_thread

DAS, G. 2002. "If we were once rich, why are we wow poor?" Indian Unbound. New Delhi: Penguin.

DAS, S. 2008. “A flux of pink Indians.”Vice Magazine. 2 Dec. 2015. http://www.viceland. com/int/v15n2/htdocs/flux_pink_indians.php?country=us

DAsGupta, P. 2006. "The power of pink.” The Indian Express.

Dubois, J. A. 2000. Hindu Manners, Customs and Ceremonies. New Delhi: Rupa \& Co.

Dumont, L. 1981. Homo Hierarchicus. The Caste System and Its Implications. University of Chicago Press.

GandHI, L. 2003. "Novelists of the 1930s and 1940s." An Illustrated History of Indian Literature in English. Ed. A. K. MEHROTRA. New Delhi: Permanent Black.

Goodwin, J. 2009. "Vigilants in pink.” Marie Claire. 16 Jan.

Gulabi Gang Organization. 2 July 2016. http://gulabigangofficial.in/ Gulabi Gang, The Pink Women of India. Shagun Rastogi Films. 7 June 2016. https://www.youtube.com/ watch?v=TfHzTY7tx6s

Human Rights W ATCH. 1999. Broken People. Caste Violence against India's "Untouchables.” New York: Human Rights Watch. "8 Injured in brutal attach on Dalit colony." The Hindu. 25 June 2016. http://www.thehindu.com/news/national/tamil-nadu/8-injuredin-brutal-attack-on-dalit-colony/article5950411 ece

International Dalit Solidarity Network (IDSN). 29 Dec. 2016. http://idsn.org/

JADHAV, N. 2003. Outcaste. New Delhi: Viking. "Kannauj girl may never be able to see from left eye." The Times of India. 25 June 2016. http://timesofindia.indiatimes.com/india/ Kannauj-girl-may-never-be-able-to-see-from-left-eye-Doctors/articleshow/8924722. cms

KHAN, A. "Gulabi gang on the prowl in Banda." The Hindu. 24 June 2016. http://www. thehindu.com/todays-paper/tp-national/tp-otherstates/gulabi-gang-on-the-prowl-inbanda/article3087761.ece

LANGA M. "Pregnant Dalit woman beaten up for not disposing of cow carcas." The Hindu. 1 Jan 2017. http://www.thehindu.com/todays- paper/tp-national/Pregnant-Dalit-womanbeaten-up-for-not-disposing-of-cow- carcass/article15000501.ece

Loomba, A. 1988. Colonialism/Postcolonialism. London: Routledge.

Manjoo, R. 2014. Report of the Special Rapporteur on Violence against Women, Its Causes and Consequences. Human Rights Council. United Nations. 2 Jan. 22017. https://documents-dds-ny.un.org/doc/UNDOC/GEN/G14/128/27/PDF/G1412827. pdf?OpenElement 
NAG, K. 2009. “A tale of two Dalit women.” The Times of India. 20 May 2016. http://blogs. timesofindia.indiatimes.com/masala-noodles/a-tale-of-two-dalit/

Pal, S. \& Berthod, A. 2008. Moi, Sampat Pal, Chef de Gang en Sari Rose. Paris: Pocket.

----. 2008. El ejercito de los saris rosas. Barcelona: Booket.

----. 2009. Warrior in a Pink Sari. Delhi: Zubaan.

PANIKER, A. 2014. La sociedad de castas. Religión y política en la India. Barcelona: Kairós.

PARWAR, U. 2003 \& 2008. The Weave of My Life. A Dalit Woman's Memoir. Kolkata: Stree.

Rao, D. V. 2006. Dr. B. R. Ambedkar. Champion of Human Rights in India. New Delhi: Manak Publications.

Roy, A. 1997. The God of Small Things. London: HarperCollins.

SAner, E. (2011, March 8). Sampat Pal Devi. The Guardian. Retrieved May 20 2016, from http://www.guardian.co.uk/world/2011/mar/08/sampat-pal-devi-100-women Shah, G. 2001. Dalit Identity and Politics. Delhi: Sage Publications.

Shrinivasan, R. (2011, June 13). "When some are less than equal." The Times of India. 20 May 2016. http://timesofindia.indiatimes.com/city/goa/When-some-are-less-thanequal/articleshow/8834359.cms

SpIVAK, G. "Can the Subaltern Speak?” 10 March 2015. http://abahlali.org/files/Can_the_ subaltern_speak.pdf

Srivastava, A. "Rajasthan's Dalit women celebrate 'liberty' at temple.” Indo-Asian News Service/ India Vision. 20 May 2016. http://www.dnaindia.com/india/report-rajasthans-dalit-women-celebrate-liberty-at-temple-1557275

SRIVAStaVA, P. “Dalit Women Stripped, Beaten, Paraded Naked in UP Village.” India Today. 28 Dec. 2016. http://indiatoday.intoday.in/story/dalit-women-paraded-naked-in-uttarpradesh/1/438628.html. The Gulabi Gang. Journeyman Pictures, SBS Australia, 2010. 18 May 2016. from https:/www.youtube.com/watch?v=28WO-0U5Gts. "The perils of being a Dalit in India.” The Hindu . 6 August 2015. http:/www.thehindu .com/specials/ in-depth/the-perils-of-being-a-dalit- in-india/article7180134.ece. The Unstoppable Indians: The Gulabi Gang. New Delhi TV. 18 May 2016. http://www.ndtv.com/video/ player/the-unstoppable-indians/the- gulabi-gang-135096?browserpush=true

Viramma \& Racine, J. 1997. Viramma: Life of an Untouchable. London: Verso. Witness Gulabi Gang. Part I \& II. Aljazeera English Productions. 18 May 2016. http://www. youtube.com/watch?v=opZz87S2v6M\&NR=1 (Part 1). http://www.youtube.com/ watch?v=46q5UfLSewg\&feature $=$ relmfu (Part 2). 